\title{
PENERAPAN MOTIF HIAS PADA KAIN JADI DENGAN MENGGUNAKAN KOMBINASI TEKNIK PAINTING DAN BORDIR
}

\author{
Ririn Pebrianti ${ }^{1}$, Ni Kt. Widiartini ${ }^{2}$, I Gede Sudirtha ${ }^{3}$ \\ Jurusan Pendidikan Kesejahteraan Keluarga \\ Universitas Pendidikan Ganesha \\ Singaraja, Indonesia \\ e-mail: ririnp207@gmail.com, ketut.widiartini@yahoo.com' \\ gede,sudirtha@yahoo.com@undiksha.ac.id
}

\begin{abstract}
Abstrak
Penelitian jenis eksperimen ini bertujuan untuk mengetahui hasil penerapan motif hias pada kain jadi dengan menggunakan kombinasi teknik painting dan bordir dilihat dari prinsipprinsip dan unsur-unsur desain berdasarkan 7 aspek kualitas yaitu bentuk, warna, tekstur, keselarasan, irama, pusat perhatian dan unity (keseluruhan). Metode pengumpulan data yang digunakan dalam penelitian ini yaitu metode observasi. Instrumen yang digunakan dalam penelitian ini yaitu lembar observasi (lembar uji panelis) berdasarkan tolak ukur kualitas dan dikonversi dengan menggunakan skala 3 (baik, cukup, tidak baik) dan diujikan secara organoleptik kepada 19 orang panelis terlatih. Data uji kualitas dianalisis dengan menggunakan teknik deskriptif kuantitatif. Hasil penelitian ini diperoleh bahwa kualitas penerapan motif hias pada kain jadi dengan menggunakan kombinasi teknik painting dan bordir berdasarkan 7 aspek kualitas yaitu (1) bentuk yang memperoleh skor 2,72 dalam kategori baik, (2) warna memperoleh skor 2,80 dalam kategori baik, (3) tekstur memperoleh skor 2,77 dalam kategori baik, (4) keselarasan memperoleh skor 2,77 dalam kategori baik, (5) irama memperoleh skor 2,80 dalam kategori baik, (6) pusat perhatian memperoleh skor 2,85 dalam kategori baik, (7) unity (keseluruhan) memperoleh skor 2,80 dalam kategori baik.
\end{abstract}

Kata kunci : bordir, kualitas, motif hias, painting, penerapan.

\begin{abstract}
This experimental type research aims to find out the results of the application of decorative motif on the finished fabric by using a combination of painting and embroidery techniques seen from the principles and design elements based on 7 aspects of quality, namely shape, color, texture, harmony, rhythm, attention and unity (whole). Data collection methods used in this research is the method of observation. The instrument used in this research is the observation sheet (panelist test sheet) based on the quality benchmark and converted by using scale 3 (good, enough, not good) and organoleptically tested to 19 trained panelists. Quality test data were analyzed by using quantitative descriptive technique. The result of this research shows that the quality of application of decorative motif on finished fabric by using combination of painting and embroidery technique based on 7 aspects of quality that is (1) the form that got score 2,72 in good category, (2) color got score 2,80 in good category , (3) the texture obtained a score of 2.77 in either category, (4) the alignment obtained a score of 2.77 in either category, (5) the rhythm obtained a score of 2.80 in either category, (6) the center of attention earned a score of 2.85 in either category, (7) unity (whole) earned a score of 2.80 in either category.
\end{abstract}

Keywords: embroidery, quality, decorative motif, painting, application. 


\section{PENDAHULUAN}

Pada zaman purba manusia telah memiliki kebiasaan untuk menutupi tubuh dengan rantai dari kulit kerang, kulit kayu, daun-daunan, kulit binatang bahkan ada yang menutupi tubuh dengan lumpur dan menghias tubuh dengan cara melukis wajah serta dengan cara mentato tubuh. Dahulu tujuan manusia semata-mata hanya sekedar untuk menutupi dan melindungi tubuh dari gejala alam, cuaca, iklim, dan gangguan binatang, Arifah, A Riyanto (2003:44). Tetapi semakin lama nilai-nilai dalam berbusana semakin berkembang sedemikian rupa sehingga memenuhi rasa estetis (keindahan) serta dibuat untuk menutupi kekurangan bentuk tubuh yang kurang sempurna, dan dapat memperindah penampilan seseorang. Perkembangan busana tentu saja didukung oleh semakin majunya peradaban dan kebudayaan manusia, oleh karena itu dengan adanya model busana yang beranekaragam, maka semakin tinggi nilai estetika dan harga jual pada busana tersebut. Untuk itu, para designer yang khususnya di dunia mode terus berlomba-lomba untuk menciptakan inovasi baru dengan berbagai motif hias yang bertujuan menjadikan penampilan seseorang menjadi menarik, tampan dan anggun.

Desain merupakan bentuk rumusan dari suatu proses pemikiran, desain yang dituangkan dalam wujud gambar yang merupakan pengalihan gagasan kongkrit dari sang perancang kepada orang lain.

Desain struktur merupakan desain yang mengacu pada kegunaan benda, struktur, bentuk dan kontruksinya, skala ruang dan dimensi manusia, segi-segi ergonomic (kenyamanan), bahan dan keawetannya. Desain dekoratif merupakan pola rancangan yang memperhitungkan segi-segi keindahan penampilan benda pakai.

Desain yang baik adalah desain yang berhasil menampilkan desain dekoratif yang terpadu. Desain dekoratif dapat juga digabungkan pada desain struktural asal dapat mencapai keserasian antara keduanya.

Menurut Suhersono Hery (2005: 11), motif adalah desain yang dibuat dari bagian-bagian bentuk, berbagai macam garis atau elemen-elemen, yang terkadang begitu kuat dipengaruhi oleh bentuk-bentuk alam benda, dengan gaya dan ciri khas sendiri. motif-motif yang biasa digambarkan pada tekstil yang diambil dari alam sekitar yang dirangkum dalam kelompok-kelompok motif hias yaitu, bentuk flora, bentuk fauna, bentuk pemandangan, bentuk geometris dan bentuk abstrak.

Soegeng Teokio M (2000:1), berpendapat bahwa, ragam hias untuk suatu benda pada dasarnya merupakan sebuah pedandan yang diterapkan guna mendapatkan keindahan yang dipadukan. Dalam menghias kain atau tekstil ada beberapa teknik hias seperti, seperti teknik bordir, teknik painting, teknik sablon, sulaman, air brush, batik, ikat celup (jumputan), lekapan benang, smoc, fecwook, beading dan lain sebagainya. Teknik paiting dan bordir merupakan teknik yang biasanya diterapkan tersendiri pada kain atau busana. Oleh karena itu, untuk menciptakan suatu karya seni yang lebih kreatif, indah dan memiliki nilai seni yang lebih dari karya seni yang biasanya dalam penelitian ini teknik painting dan bordir dikombinasikan dalam penerapan motif hias sehingga mendapat karya seni yang baru dan lebih menarik.

Teknik painting merupakan bagian dari serface desain melalui teknik polesan kuas, spon dan lain sebagainya pada permukaan kain, Juliana Netty (2013).

Sulam atau bordir adalah hiasan dari benang yang dijahitkan pada kain. Dengan berkembangnya teknologi pengerjaan sulam (bordir) meningkat dengan memakai alat bantu 
berupa mesin jahit, dan mesin khusus untuk bordir. Sulam (bordir) tidak hanya menggunakan benang dan kain saja. Untuk menyulam selain menggunakan benang juga menggunakan bahan lain seperti pita, serat alam, bahkan ada yang dikombinasi dengan manik-manik atau payet. Sedangkan bahan yang disulam sekarang tidak hanya menggunakan kain saja, tetapi sudah meggunakan bahan lain seperti kulit, tenunan serat alam dan sebagainya, Suhersono Heri, (2004 : 6).

Bahan dari tekstil yang dapat dihasilkan dengan serat alam dan serat sintetis. Untuk serat alam berasal dari kapas dan disebut katun. Katun sebenarnya adalah nama serat tetapi juga menjadi sebutan untuk bahan tenun dari serat katun, dari semua jenis serat yang ada, pemakai kapas adalah yang paling tinggi. Dalam eksperimen ini peneliti menggunakan serat alami, karena pada penerapan motif hias teknik painting dan bordir harus memperhatikan sifat atau karakteristik dari bahan tekstil. Pada bahan alami atau kapas yang mempunyai sifat seperti kuat, mudah menyerap air, tahan pada bahan pembersih, tidak tahan pada asam pekat, tidak berbulu dan dingin, sehingga bisa sejuk dipakai pada daerah tropis seperti di Indonesia.

Tekstil yang terbuat dari serat alami yang mempunyai sifat di atas banyak macamnya maka dalam eksperimen ini, peneliti hanya menggunakan satu bahan tekstil dari serat alami yaitu katun Jepang. Katun Jepang sekilas sama seperti kain katun biasa pada umumnya. Tetapi jika diperhatikan, ada beberapa ciri khusus. Katun Jepang memiliki serat kain yang lembut cocok untuk berkulit sensitif. Terbuat dari 100\% katun kualitas premium sehingga nyaman, halus, warna mengkilap atau glossy, warna tidak luntur dan tidak mudah pudar, sering digunakan untuk bahan blous wanita, sprei dan bedcover. Harga katun Jepang lebih mahal dibandingkan kain katun biasa, karena permukaan kain lebih halus, lebih berkilau, warna lebih awet dan tahan lama.

Selama ini motif hias diterapkan pada bahan yang sudah ada sebelumnya yaitu kain satin, kain katun prima dan kain sifon. Dimana bahan satin dan katun prima mempunyai tekstur yang agak tebal. Sedangkan sifon tekstur yang tipis dan lebih trasparan. Sehingga pada penelitian ini penulis mencoba menerapkan teknik tersebut pada bahan yang lebih lembut. Penerapan teknik ini pada bahan lembut bertujuan agar kain katun Jepang dapat digunakan untuk membuat kain jadi, bahan pembuatan gaun namun mempunyai kesan lebih kasual dibandingkan dengan sifon.

Hasil penelitian Made Diah Angendari, S.Pd.,M.Pd. dan $\mathrm{Ni}$ Nyoman Sri Witari,S.Sn.,M.Ds dengan judul "Penerapan Motif Hias dengan Teknik Bordir dan Painting pada Kain", mengungkapkan bahwa teknik bordir dan painting yang diterapkan pada kain yang menggunakan dua contoh bahan tekstil dimana dua dari serat alami yaitu kain katun prima dan kain sifon mendapatkan hasil yang sangat baik. Penelitian tersebut, sudah sampai pada tahap pemilihan bahan yang baik dan menghasilkan produk berupa selendang untuk penerapan teknik bordir dan painting.

Dalam penerapan motif hias dengan teknik painting dan bordir pada tekstil haruslah diperhatikan karakteristik-karakteristik tersebut dapat menghasilkan suatu karya yang memuaskan dan suatu karya seni yang mempunyai keindahan pada bahan tekstil atau busana. Dimana pada eksperimen ini penulis mencoba menggunakan prinsip-prinsip dan unsur-unsur desain karena prinsip dan unsur desain memberikan kesatuan, proporsi, keseimbangan, pusat perhatian (aksen), irama dan unity (keseluruhan), dan keselarasan dalam suatu karya, sehingga karya itu terasa utuh, jelas, hidup dan memikat bagi yang melihat ataupun yang 
menciptakan suatu karya yang dibuat dan dapat diterima oleh masyarakat.

Dimana prinsip dan unsur desain mempunyai arti yaitu prinsip desain merupakan suatu cara teknik atau petunjuk bagaimana menerapkan unsur-unsur kedalam suatu desain. Prinsip-prinsip desain ini meliputi: kesatuan, proporsi, keseimbangan, pusat perhatian (aksen), irama dan unity (keseluruhan). Sedangkan Unsur desain adalah unsur-unsur yang digunakan untuk mewujudkan desain, sehingga orang lain dapat membaca atau melihat desain tersebut. Unsurunsur desain meliputi garis, arah, bentuk, ukuran, tekstur, nilai gelap terang dan warna.

Kreativitas yang akan mengasilkan suatu karya yang bagus dan indah, dengan menggunakan penerapan dua bentuk karya seni antara teknik painting dan bordir. Dalam eksperimen ini akan diuji coba dan diteliti dengan memadukan atau mengkombinasikan teknik painting dan bordir. Dimana bahan tekstil teknik painting dikerjakan terlebih dahulu dan dilanjutkan dengan teknik bordir karena sebelumnya eksperimen ini sudah dibuat tetapi hanya dalam bentuk bahan tekstil saja belum dalam bentuk produk jadi. Peneliti mencoba membuat benda jadi yang cocok diterapkan pada teknik painting dan bordir adalah kain jadi karena kain jadi banyak diminati khusus dikalangan wanita umat Hindu terutama di Bali, kain jadi berfungsi untuk menghadiri suatu acara misalnya seperti acara pernikahan, persembahyangan, dan acara-acara besar lainnya.

Berdasarkan latar belakang di atas, penulis mengangkat sebuah judul penelitian yaitu "Penerapan Motif Hias pada Kain Jadi dengan Menggunakan Kombinasi Teknik Painting dan Bordir". Dimana dalam uji kualitas dilihat dari prinsip-prinsip dan unsur-unsur desain berdasarkan 7 aspek kualitas yaitu : bentuk, warna, tekstur, keselarasan, irama, pusat perhatian, dan unity (keseluruhan).
Penelitian ini dilakukan dengan tujuan menambah nilai seni dan dapat mengembangkan kreatifitas dalam mengkreasikan teknik-teknik desain dekorasi. Selain itu juga, alasan penulis memadukan atau mengkombinasikan kedua teknik tersebut adalah agar masyarakat bisa lebih efisien dalam memilih bahan atau tekstil. Dengan hanya membeli selembar kain atau tekstil saja masyarakat telah mendapatkan bahan tekstil yang sudah dihiasi beberapa jenis teknik dekoratif.

\section{METODE PENELITIAN}

Jenis penelitian yang digunakan adalah penelitian eksperimen. Penelitian eksperimen adalah suatu cara pendekatan dimana gejala atau objek yang akan diteliti itu dibuat atau ditimbulkan dengan sengaja, Agung Gede. A.A (1999). Sedangkan metode eksperimen yaitu metode penelitian yang dipergunakan untuk meneliti suatu objek dengan melakukan suatu percobaan secara nyata di lapangan, Arikunto Suharsimi (2006)

Berdasarkan pendapat para ahli diatas, maka peneliti dapat menyimpulkan bahwa penelitian eksperimen adalah suatu jenis penelitian dimana objek yang akan diteliti ditimbulkan secara sengaja dengan melakukan percobaan secara nyata di lapangan dengan maksud untuk melihat hasil dari perlakuan.

Terkait dengan tujuan penelitian eksperimen maka penelitian ini dilakukan untuk penerapan motif hias, yaitu tepatnya mengetahui hasil penerapan motif hias pada kain jadi dengan menggunakan kombinasi teknik painting dan bordir dengan menggunakan prinsip-prinsip dan unsur-usur desain. Sehingga bisa dievaluasi oleh panelis untuk mendapatkan hasil dari penilaian painting dan bordir.

Rancangan penelitian eksperimen yang merupakan gambaran dari proses 
atau langkah-langkah dari penelitian eksperimen dapat dilihat pada Bagan 1 seperti dibawah ini.

\section{Bagan 1. Rancangan penelitian}

Dari rancangan di atas dapat digambarkan proses penelitian yang dilakukan dengan eksperimen penerapan motif hias pada kain jadi dengan menggunakan kombinasi teknik painting dan bordir. Beberapa tahapan yang dilakuakan yaitu dari Persiapan (bahan dan alat), Eksperimen (painting dan bordir), Hasil jadi, dan Uji panelis.

Persiapan alat yang diperlukan untuk painting: (a) Pensil dan penghapus, b) Kertas HVS, c) Penggaris, d) Kertas minyak, e) Karbon kain, f) Jarum pentul, g) Kuas, h) Gelas air, i) tissue, j) Setrika, k) Kipas angin, I) Meteran, m) Gunting. Sedangkan bahan yang digunakan untuk paiting antara lain : a) Cat tekstil, b) Air.

Persiapan alat yang diperlukan untuk bordir antara lain : a) Mesin bordir listrik, b) Pemidangan, c) Gunting bordir, d) Jarum jahit mesin, e) Lain-lain, alat yang lain dipergunakan sama dengan alat painting, mulai dari alat tulis seperti : pensil, penghapus, kertas HVS, kertas minyak, karbon, alat jahit, penggaris, meteran, kain, jatum pentul, setrika, dan gunting kain. Fungsi masing-masing alat seperti yang sudah dijelaskan diatas. Sedangkan bahan yang digunakan untuk bordir antara lain : a) Bahan tekstil yang digunakan yaitu kain katun Jepang, b) benang yang digunakan yaitu benang bordir bewarna hitam dan merah.

adalah :

Proses pembuatan painting

a) Mencuci kain, kain yang akan digunakan adalah katun Jepang dicuci terlebih dahulu. Pada umumnya untuk jenis kain katun Jepang dicuci dengan sabun (deterjen). Kemudian dibilas dan dikeringkan dengan cara dianginanginkan (jangan terkena sinar matahari langsung). Tujuan kain dicuci untuk menghilangkan kotoran atau kanji yang melekat diatas kain, sehingga cat tekstil bisa menempel dan lebih meresap dengan baik, serta warna cat tekstil lebih terlihat cerah.

b) Kain disetrika, setelah kering setrika kain supaya saat dilukis permukaan kain licin dan bersih.

c) Membuat desain motif, yang dilukis pada selembar kertas HVS.

d) Menjiplak desain pada kertas minyak, lalu dijiplak pada kain katun Jepang dengan menggunakan karbon dan rader.

e) Teknik paiting (melukis).

Sebelum melukis tes daya serap kain dengan cara menyapukan air dengan kuas jika air cepet melebar, berarti daya serap kain yang digunakan cukup tinggi sebaiknya jangan mencampurkan air terlalu banyak ke dalam cat. Sebelum menyapu kuas dengan cat basahi kuas terlebih 
dahulu, kemudian lap dengan tisu jangan menyapu kuas dalam keadaan kering.

Dilanjutkan menggunakan proses painting yang dilakukan terlebih dahulu adalah cat dasar motif yang dilukis lebih dahulu dengan cat tekstil (cat aclirik) warna putih, yang bertujuan untuk menetralisir warna kain dan akan lebih menghaluskan tekstur pada kain. Campurkan cat tekstil dengan sedikit air sampai mencapai kekentalan yang diinginkan. Sapukan cat tekstil pada tengah muka kain, kupu-kupu, bunga dan daun, satu demi satu sesuai tekstur motif yang dijiplak. Tunggu sampai setengah kering, baru kemudian diteruskan dengan proses selanjutnya.

Proses bordir yang dilakukan antara lain :

(a). Membentangkan kain yang sudah dilukis pada pemidangan, tujuannya agar kain mudah dibordir.

(b). Penerapan teknik bordir, kain yang sudah dilukis bagian sisi motif painting dibordir sehingga kelihatan rapi, dan teknik bordir dipadukan pada bagian sari bunga untuk membuat gradasi warna pada bunga.

(c). Finishing, gunting sisa-sisa benang yang ada pada perukaan kain sehingga tampak rapi.

Hasil produk kain jadi ditinjau dari 7 aspek kualitas yaitu : bentuk, warna, tekstur, keselarasan, irama, pusat perhatian dan unity (keseluruhan). Uji kualitas menggunakan 19 orang panel terlatih. Data dianalisis dan ditarik suatu kesimpulan.
Adapun analisis data yang digunakan dalam penelitian ini yaitu metode analisis data deskriptif kuantitatif yaitu suatu cara pengolahan data yang dilakukan dengan jalan menyusun secara sistematis dalam bentuk angka-angka atau persentase mengenai objek yang diteliti sehingga memperoleh kesimpulan umum (Agung, 1999). Variabel merupakan ukuran atau ciri yang dimiliki oleh anggota-anggota suatu kelompok yang berbeda dengan yang dimiliki oleh kelompok lain.

Instrumen yang digunakan dalam penelitian ini berupa lembar uji kualitas yang memuat tolak ukur yang kemudian diberikan pada setiap panelis untuk menilai kualitas terhadap suatu produk yang disajikan oleh penulis.. Data yang diperoleh dari penilaian terhadap hasil eksperimen oleh panelis berupa skor kemudian diubah dalam bentuk persentase.

Rumus yang digunakan yaitu (Arikunto, 2002). Acuan tersebut digunakan untuk menentukan kualitas penerapan motif hias pada kain jadi dengan menggunakan kombinasi teknik painting dan bordir yang dilihat dari kualitas bentuk, warna, tekstur, keselarasan, irama, pusat perhatian dan unity (keseluruhan) berdasarkan rumus pedoman konversi menggunakan skala 3 (tiga) adalah sebagai berikut:

$$
M=\frac{\sum X}{N}
$$

Tabel 1. Skala 3 (tiga) 
Jurnal Bosaparis: Pendidikan Kesejahteraan Keluarga

Volume 9, Nomor 1, Maret 2018

Rentang Skor

Klasifikasi/Predikat

\begin{tabular}{cc}
\hline $2,33-3,00$ & Baik \\
\hline $1,67-2,32$ & Cukup \\
\hline $1,01-1,66$ & Buruk
\end{tabular}

HASIL

DAN

PEMBAHASAN

Uji kualitas berupa skor dan hasil perolehan serta peritungan rata-rata mengenai kualitas penerapan motif hias pada kain jadi dengan menggunakan kombinasi teknik painting dan bordir sesuai dengan kualitas berdasarkan bentuk, warna, tekstur, keselarasan, irama, pusat perhatian, unity (keseluruhan).

Tabel 2. Hasil Uji Kualitas Penerapan motif hias pada kain jadi dengan menggunakan kombinasi teknik painting dan bodir

Aspek Yang Dinilai $\Sigma \mathrm{X}$ Jumlah Sampel

(N)

Data dalam penelitian ini seluruhnya dikumpulkan dengan menggunakan lembar observasi berupa lembar uji kualitas terhadap 19 orang panelis terlatih. Data yang diperoleh dianalisis menggunakan teknik analisis deksriptif kuantitatif sehingga diperoleh kesimpulan.

\begin{tabular}{lllll}
\hline Bentuk & 51 & 19 & 2,72 & Baik \\
\hline Warna & 53 & 19 & 2,80 & Baik \\
\hline Tekstur & 52 & 19 & 2,77 & Baik \\
\hline Keselarasan & 52 & 19 & 2,77 & Baik \\
\hline Irama & 53 & 19 & 2,80 & Baik \\
\hline Pusat Perhatian & 54 & 19 & 2,85 & Baik \\
\hline Unity (Keseluruhan) & 53 & 19 & 2,80 & Baik \\
\hline
\end{tabular}


Berdasarkan tabel diatas diperoleh hasil uji kualitas penerapan teknik motif hias pada kain jadi dengan menggunakan kombinasi teknik painting dan bordir, berdasarkan 7 aspek yaitu bentuk, warna, tekstur, keselaraan, irama, pusat perhatian dan unity (keseluruhan). Aspek pertama yaitu bentuk yang memperoleh skor 2,72 berada dalam kategori baik, aspek kedua yaitu warna memperoleh skor 2,80 berada dalam kategori baik, aspek ketiga yaitu tekstur memperoleh skor 2,77 berada dalam kategori baik, aspek keempat yaitu keselarasan memperoleh skor 2,77 berada dalam kategori baik, aspek kelima yaitu irama memperoleh skor 2,80 berada dalam kategori baik, aspek keenam yaitu pusat perhatian memperoleh skor 2,85 berada dalam kategori baik, dan terakhir aspek unity (keseluruhan) memperoleh skor 2,80 berada dalam kategori baik.

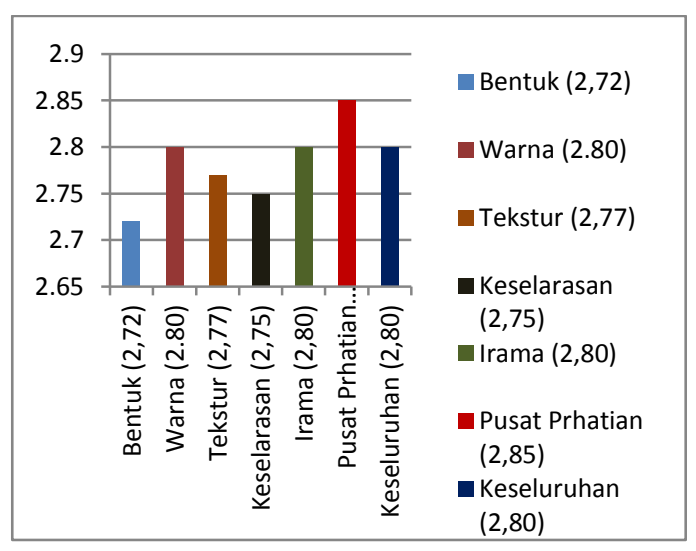

Diagram 1 Hasil Uji Penerapan Teknik Motif Hias pada Kain Jadi dengan Menggunakan Kombinasi Teknik Painting dan Bordir.

Hasil uji kualitas penerapan motif hias pada kain jadi dengan menggunakan kombinasi teknik painting dan bordir dapat dijabarkan sebagai berikut:

1. Aspek Bentuk

Bentuk adalah penilaian berdasarkan susunan dari garis yang membentuk suatu ruang atau bidang bentuk tersebut dapat berupa bentuk leher, kerah, lengan, rok dan lain-lain.
Motif hias dengan menggunakan teknik painting dan bordi yang diterapkan pada serat alami yaitu katun Jepang. Lukisan yang sudah jadi pada bagian sisi motif dan sari bunga dibordir dengan menggunakan warna hitam dan merah.

\section{Aspek Warna}

Warna adalah penilaian berdasarkan unsur rupa yang mudah ditangkap oleh mata serta memberi rasa keindahan yang dapat mengungkapkan perasaan desainer atau karakter gambar busana yang dirancang seperti sifat, karakter, dan citra yang berbeda-beda.

\section{Aspek Tekstur}

Tekstur adalah penilaian yang berkaitan dengan sifat permukaan dari bahan tekstil yang dapat dilihat dan dirasakan, misalnya kaku, lembut, kasar, tebal, tipis, halus dan transparan.

4. Aspek Keselarasan

Keselarasan merupakan penilaian tentang persamaan, penyesuaian dan keserasian antara macam-macam unsur desain yaitu selaras antara garis dan bentuk, tekstur dan warna sehingga tercapai kesatuan yang harmonis.

5. Aspek Irama

Irama (Ritme) adalah penilaian yang berkaitan dengan suatu gerakan teratur yang menentukan selaras atau tidaknya suatu desain busana dan dapat mengalihkan pandangan mata dari suatu bagian ke bagian lain.

\section{Aspek Pusat Perhatian (Centre of Interest)}

Pusat Perhatian (Centre of Interest) adalah penilaian berdasarkan suatu bagian dalam desain busana yang lebih menarik dari bagian-bagian lainnya yang bisa didapat dari penggunaan warna, garis, bentuk dan ukuran yang kontras serta pemberian hiasan sehingga dapat menutupi kekurangan bentuk tubuh.

7. Unity (Keseluruhan)

Unity (Keseluruhan) merupakan penilaian tentang sesuatu yang memberi kesan adanya keterpaduan tiap unsur. Tergantung pada unsur dan prinsip desain yang digunakan agar selaras dan 
seimbang agar benda yang dibuat serasi dengan lainnya.

Beberapa panelis berpendapat bahwa teknik ini dapat dijadikan alternatif dalam membuat kain jadi sehingga waktu yang habiskan dalam pembuatan lebih efisien. Kain katun Jepang yang mempunyai sifat seperti kuat, mudah menyerap air, tahan pada bahan pembersih, tidak tahan pada asam pekat, tidak berbulu dan dingin, sehingga bisa sejuk dipakai pada daerah tropis seperti di Indonesia.

Dari pemaparan di atas, hasil penelitian ini berguna bagi pendidik khususnya Jurusan Tata Busana, dimana materi penerapan motif hias dengan menggunakan kombinasi teknik painting dan bordir ini dapat diterapkan pada beberapa mata kuliah misalnya teknik aplikasi menghias tekstil. Materi ini dapat menjadi tambahan ilmu yang baru dan segar sehingga dapat menambah minat peserta didik dalam mempelajari ilmu aplikasi menghias tekstil.

Pada penelitian penerapan motif hias pada kain jadi dengan menggunakan kombinasi teknik painting dan bordir dapat dijelaskan kendala-kendala yang didapat pada penelitian serta penanggulangannya.

Dimulai pada saat melukis motif pada kain katun Jepang, apabila menggunakan campuran air yang terlalu banyak akan menyebabkan cat lebih cepat menyebar atau belobor pada permukaan kain, karena kain katun Jepang teksturnya tipis (trasparan), lembut dan seratnya agak jarang. Sehingga peneliti dalam melukis pada kain katun Jepang menggunakan cat yang persentasenya kental dan sedikit campuran air.

Kendala ke dua yang ditemukan yaitu apabila dalam menggulung benang pada skoci terlalu penuh dapat menyebabkan benag kusut dan putusputus waktu membodir. Sebaiknnya saat menggulung benang jangan terlalu penuh untuk menghindari agar benang tidsk kusut dan putus-putus.
Selanjutnya kendala ketiga yang ditemukan yaitu pada saat selesai membordir. Kain yang sudah selesai dipainting dan cat sudah kering kain dibentangan pada pemidangan sehingga kain menjadi kaku dan mudah untuk dibordir, ternyata pada saat membentangkan dan penarikan kain dalam pemidangan diperoleh serat kain ikut tertarik yang menyebabkan kain menjadi mengkerut, karena kain katun Jepang teksturnya tipis (trasparan), lembut dan seratnya agak jarang.

\section{SIMPULAN}

Berdasarkan hasil penelitian yang telah dilakukan, maka dapat disimpulkan bahwa hasil uji kualitas penerapan motif hias dengan menggunakan kombinasi teknik painting dan teknik bordir dilihat dari prinsip-prinsip dan unsur- unsur desain berdasarkan 7 aspek kualitas yaitu (1) bentuk yang memperoleh skor 2,72 dalam kategori baik, (2) warna memperoleh skor 2,80 dalam kategori baik, (3) tekstur memperoleh skor 2,77 dalam kategori baik, (4) keselarasan memperoleh skor 2,77 dalam kategori baik, (5) irama memperoleh skor 2,80 dalam kategori baik, (6) pusat perhatian memperoleh skor 2,85 dalam kategori baik, (7) unity (keseluruhan) memperoleh skor 2,80 dalam kategori baik.

\section{SARAN}

Berdasarkan hasil penelitian dan kesimpulan, maka terdapat saran sebagai berikut.

1. Untuk penerapan motif hias pada kain jadi dengan menggunakan kombinasi teknik painting dan teknik bordir dilihat dari prinsip-prinsip dan unsur- unsur perlu mengembangkan lagi jenis cat tekstil yang digunakan dalam berbagai warna cat dan jenis kain tekstil sehingga painting dan bordir yang dihasilkan lebih beragam. 
e-Journal Penerapan Motif Hias Pada Kain Jadi dengan Menggunakan Kombinasi

Teknik Painting dan Bordir

Universitas Pendidikan Ganesha

Jurusan Pendidikan Kesejahteraan Keluarga (VolumeTahun2017)

\section{DAFTAR RUJUKAN}

Anonim. 2014. Perbedaan Katun Jepang dengan Katun Biasa. https://kaosgalauid.wordpress.com 2014/11/22/perbedaan-katunjepang-dengan-katun-biasa (di akses 18 Januari 2017).

Agung, A.A. Gede, 1999. Metodologi Penelitian, Singaraja: STKIP Singaraja.

Angendari Made Diah dan Wintari $\mathrm{Ni}$ Nyoman Sri. 2015 Penerapan Motif Hias dengan Teknik Bordir dan Painting pada Kain. Laporan Penelitian. Singaraja : Jurusan Pendidikan Kesejahteraan Keluarga.

Arifah, A Riyanto. 2003. Teori Busana. Bandung: CV. Setia Abadi.

Arikunto, Suharsimi. 2000. Prosedur Penelitian. Edisi V. Jakarta: Rineka Cipta.

Juliana, Netty. 2013. Desain Tekstil. http://nettyjuliana14.blogspot.co.id/ 2013/09/bab-i-arti-kriya-tekstilkeragaman-seni.html (di akses 30 Maret 2017)

Suhersono, Hery. 2004. Desain Motif. Jakarta : Puspa Terampil. 